\title{
Evidence that mesothelial cells regulate the acute inflammatory response in talc pleurodesis
}

\author{
E. Marchi, F.S. Vargas, M.M. Acencio, L. Antonangelo, E.H. Genofre and L.R. Teixeira
}

ABSTRACT: Intrapleural instillation of talc is used to produce pleurodesis in cases of recurrent malignant pleural effusions. The mechanisms by which pleurodesis is produced remain unknown but may involve either injury or activation of the mesothelium. The aim of the current study was to assess the inflammatory response of pleural mesothelial cells to talc in an experimental model in rabbits.

A group of 10 rabbits were injected intrapleurally with talc $\left(200 \mathrm{mg} \cdot \mathrm{kg}^{-1}\right)$ and undiluted pleural fluid was collected after 6, 24 or $48 \mathrm{~h}$ for measurement of interleukin (IL)-8, vascular endothelial growth factor (VEGF) and transforming growth factor (TGF)- $\beta 1$. Samples of pleura were studied to assess the inflammatory infiltrate and mesothelial cell viability.

The pleural fluid IL-8 concentration peaked at $6 \mathrm{~h}$, whereas VEGF and TGF- $\beta 1$ concentrations increased steadily over $48 \mathrm{~h}$. Immunohistochemistry for cytokeratin showed a preserved layer of mesothelial cells despite the intense inflammatory pleural reaction.

In conclusion, it is proposed that the mesothelial cell, although injured by the talc, may actively mediate the primary inflammatory pleural response in talc-induced pleurodesis.

KEYWORDS: Inflammatory mediators, pleural effusions, pleurodesis

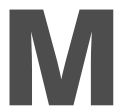

alignant pleural effusion is a common complication of advanced cancer [1] and, despite the fact that patients with this malignant complication have a short life expectancy, the prompt control of the effusion is imperative to obviate discomfort of persistent cough and dyspnoea. Drainage of the pleural cavity and instillation of a sclerosing agent is the standard method to produce pleural symphysis and prevent fluid re-accumulation [2-4]. Talc, instilled either by slurry or by thoracoscopy [5-7], has been shown to produce more than $90 \%$ success in the control of recurrent malignant pleural effusion $[8,9]$. The mechanism by which talc produces a pleurodesis remains unclear. Talc may injure the mesothelial layer or may stimulate monocytes or mesothelial cells to produce a local reaction mediated by major inflammatory cytokines [10,11]. Among the cytokines involved in the acute inflammatory response, interleukin (IL)-8 and vascular endothelial growth factor (VEGF) are the main mediators of leukocyte activation and vascular capillary response to inflammation, respectively [12-14], whereas transforming growth factor (TGF)- $\beta 1$ and fibroblast growth factor (FGF) are involved in the activation of fibroblasts to produce and deposit collagen $[15,16]$.
In animal and clinical models of pleurodesis, it is difficult to isolate the response of the mesothelial cells to the sclerosing agent because of the active multicellular population found in the pleural space. The purpose of the present study was to determine the inflammatory response of the pleural space and assess the viability of the mesothelial cells as part of the inflammatory pleural infiltrate produced by talc used for pleurodesis. The current report indicates that mesothelial cells have the potential to be the major contributor to the inflammatory response in the pleural space in talc-induced pleurodesis.

\section{METHODS}

This study was approved by the Ethics Committee of the Heart Institute (InCor), University of Sao Paulo Medical School, which oversees research involving both animals and humans.

\section{Pleural injection}

Ten New Zealand white male rabbits weighing $2.5 \mathrm{~kg}$ were anaesthetised and injected intrapleurally with $3 \mathrm{~mL}$ of talc $\left(200 \mathrm{mg} \cdot \mathrm{kg}^{-1}\right)$, which is currently used to produce pleurodesis in clinical practice (Magnesita, Bahia, Brazil; mean length $25.4 \mu \mathrm{m}$, range $6.4-50.5 \mu \mathrm{m}$ ). The talc was

\section{AFFILIATIONS}

Pleura Laboratory - Pulmonary Division, Heart Institute (InCor), University of São Paulo Medical School, São Paulo, Brazil.

\section{CORRESPONDENCE}

E. Marchi

R. Lucia B. Passarin

590 - Ap 42

13.216-351

Jundiaí

São Paulo

Brazil

Fax: 551145221775

E-mail: evmarchi@uol.com.br

Received:

March 162006

Accepted after revision:

July 072006

\section{SUPPORT STATEMENT}

The present study was supported by Foundation to Support Research of the State of Sao Paulo (99/02777-3 and 03/00833-0) and National Council of Research (CNPq), Brazil. 
suspended under sterile conditions in an endotoxin-free saline solution. The protocol of pleural injection has been described in detail previously $[17,18]$. After 6,24 or $48 \mathrm{~h}$, the animals were sacrificed and, after exposure of the diaphragm via a midabdominal incision, the pleural fluid was aspirated and processed for cytokine measurements.

\section{Cytokine analysis}

IL-8 (OptEIA, rabbit IL-8 set; Pharmingen, San Diego, CA, USA), VEGF (R\&D System, Inc., Minneapolis, MN, USA) and TGF- $\beta 1$ (R\&D System, Inc.) were measured by ELISA as described previously [13].

\section{Tissue samples}

Samples of lung including the visceral pleural tissue were fixed in $10 \%$ formalin for $48 \mathrm{~h}$ and processed for histological analysis. The slides were stained by immunohistochemistry for cytokeratin (AE1/AE3: Dako Cytomation, Produktionsgej, Denmark) following the manufacturer's directions.

\section{Statistical analysis}

Data are expressed as mean $\pm \mathrm{SD}$. One-way ANOVA was used to compare differences among subgroups and the Tukey test was used to perform multiple comparison procedures. A p-value $<0.05$ was accepted as significant.

\section{RESULTS}

\section{Cellular response}

\section{WBC}

Total white blood cell counts (WBC) were significantly greater at 6 and $24 \mathrm{~h}$ in comparison with $48 \mathrm{~h}(19,430 \pm 1,750$ and $18,810 \pm 5,660$ versus $11,270 \pm 1,190$ cells $\cdot \mathrm{mm}^{-3}$, respectively; $\mathrm{p}<0.05$; table 1).

\section{Neutrophil percentage}

Similar to WBC levels, neutrophil percentages were increased in the first $6 \mathrm{~h}(74 \pm 6)$ in comparison to $24 \mathrm{~h}(60 \pm 5 ; \mathrm{p}<0.05)$ and $48 \mathrm{~h}(24 \pm 8 ; \mathrm{p}<0.001)$.

\section{IL-8}

Concentrations of IL-8 increased as soon as $6 \mathrm{~h}$ $\left(797 \pm 335 \mathrm{pg} \cdot \mathrm{mL}^{-1}\right)$ after the pleural space was exposed to talc, and remained elevated until $24 \mathrm{~h}\left(665 \pm 125 \mathrm{pg} \cdot \mathrm{mL}^{-1}\right)$, decreasing significantly after $48 \mathrm{~h}\left(134 \pm 33 \mathrm{pg} \cdot \mathrm{mL}^{-1} ; \mathrm{p}<0.001\right.$; table 2).

\begin{tabular}{l} 
TABLE 1 $\begin{array}{l}\text { Levels of pleural fluid white blood cells } \\
\text { (WBC, cells } \cdot \mathrm{mm}-3) \text { and neutrophils }(\% \mathrm{~N}) \text { in } \\
\text { talc-injected }\left(200 \mathrm{mg} \cdot \mathrm{kg}^{-1}\right) \text { rabbits after } 6,24 \\
\text { and } 48 \mathrm{~h}\end{array}$ \\
\multicolumn{1}{c}{$\mathbf{\text { WBC }}$} \\
\hline $\mathbf{6} \mathbf{~}$ \\
$\mathbf{2 4} \mathbf{~}$ \\
$\mathbf{4 8} \mathbf{~}$
\end{tabular}

\section{VEGF}

Unlike IL-8, VEGF levels increased with time. At $48 \mathrm{~h}$, the VEGF concentration $\left(689 \pm 115 \mathrm{pg} \cdot \mathrm{mL}^{-1}\right)$ was significantly $>6 \mathrm{~h}$ $\left(164 \pm 64 \mathrm{pg} \cdot \mathrm{mL}^{-1} ; \quad \mathrm{p}<0.001\right)$ and $24 \mathrm{~h} \quad\left(336 \pm 188 \mathrm{pg} \cdot \mathrm{mL}^{-1}\right.$; $\mathrm{p}<0.05)$.

\section{TGF- $\beta 1$}

Similarly to VEGF, the concentrations of TGF- $\beta 1$ also increased over time. At 48 and $24 \mathrm{~h}$, the levels were significantly $>6 \mathrm{~h}$ $\left(1,135 \pm 223\right.$ and $931 \pm 60$ versus $385 \pm 104 \mathrm{pg} \cdot \mathrm{mL}^{-1} ; \mathrm{p}<0.001$ and $\mathrm{p}<0.05$, respectively).

\section{Correlations of the WBC and neutrophil percentages with cytokine IL-8}

Although the WBC and neutrophil percentage showed the same behaviour as IL-8 in the pleural fluid after talc instillation, no correlation was found among these parameters (data not shown).

\section{Microscopic analysis of the pleural tissue}

Microscopic samples of the visceral pleura showed an acute inflammatory reaction as early as $6 \mathrm{~h}$ after intrapleural talc injection. The histological analysis of the slides stained by immunohistochemistry for cytokeratin revealed, in several zones throughout the slides, a preserved brown-stained monolayer of pleural mesothelial cells underlying an intense inflammatory process characterised by a multi-cell population (fig. 1).

\section{DISCUSSION}

The mechanisms by which talc produces pleurodesis remain poorly understood. The regulation of the pleural acute inflammatory response following the injection of a sclerosing agent is crucial to understanding the mechanism of pleurodesis. The findings of this study indicate that pleural mesothelial cells may actively contribute to modulate the inflammatory process in talc-induced pleurodesis.

The current findings are in accordance with previous reports, which have shown that mesothelial cells exposed to talc can actively produce pro-inflammatory IL-8 and monocyte chemotactic protein-1 [11, 13], VEGF [13], TGF- $\beta$ [15] and bFGF [16] cytokines.

\begin{tabular}{|c|c|c|c|}
\hline \multirow[t]{2}{*}{$\mathbf{T A B}$} & \multicolumn{3}{|c|}{$\begin{array}{l}\text { Levels of pleural fluid interleukin (IL)- } 8 \text {, vascular } \\
\text { endothelial growth factor (VEGF) and } \\
\text { transforming growth factor (TGF)- } \beta 1\left(\mathrm{pg} \cdot \mathrm{mL}^{-1}\right) \text { in } \\
\text { talc-injected }\left(200 \mathrm{mg} \cdot \mathrm{kg}^{-1}\right) \text { rabbits after } 6,24 \\
\text { and } 48 \mathrm{~h}\end{array}$} \\
\hline & IL-8 & VEGF & TGF- $\beta 1$ \\
\hline $6 \mathrm{~h}$ & $797 \pm 335^{\S}$ & $164 \pm 64$ & $385 \pm 104$ \\
\hline $24 \mathrm{~h}$ & $665 \pm 125^{\S}$ & $336 \pm 188$ & $931 \pm 60^{\#}$ \\
\hline $48 h$ & $134 \pm 33$ & $689 \pm 115^{\circ,+}$ & $1135 \pm 223^{\bullet}$ \\
\hline
\end{tabular}



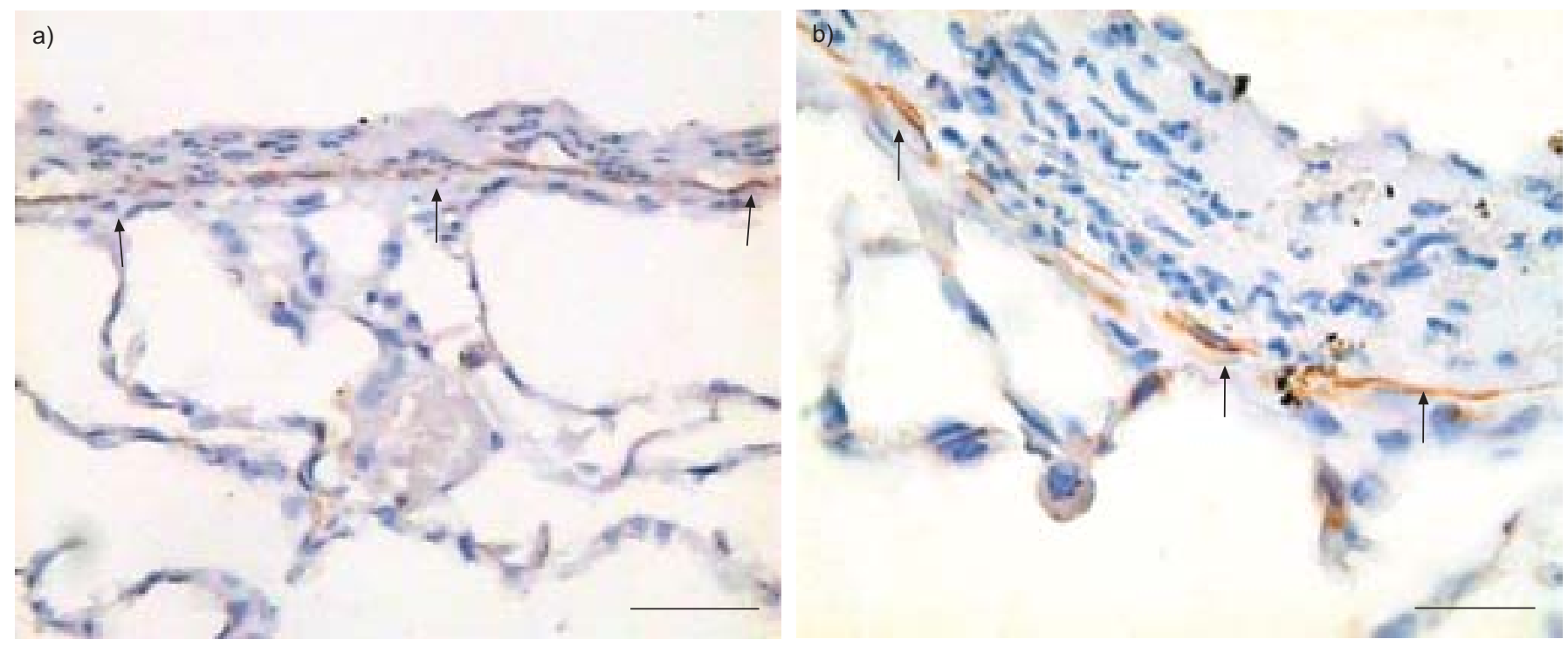

FIGURE 1. Acute pleural inflammatory reaction in rabbits, $24 \mathrm{~h}$ after talc $\left(200 \mathrm{mg} \cdot \mathrm{kg}^{-1}\right)$-injection, showing a preserved brown-stained cytokeratin positive monolayer of pleural mesothelial cells (arrows). Scale bars: a) $30 \mu \mathrm{m}$ and b) $10 \mu \mathrm{m}$.

In addition, a recent study evaluating submicroscopic features of active pleural remodelling associated with talc pleurodesis stated that talc acutely induces a prominent injury to the mesothelial cells and mesothelial cell-mesothelial basement membrane union. However, focal remesothelialisation of the denuded areas was documented [19], showing an active role of mesothelial cells in the healing process in talc pleurodesis.

The present results indicate that $\mathrm{WBC}$, neutrophil percentage and IL- 8 levels were increased in the first $24 \mathrm{~h}$, whereas VEGF and TGF- $\beta 1$ levels were initially lower and increased with time. As the population of active inflammatory cells found in the pleural space in talc-induced pleurodesis is diverse, the specific contribution of the mesothelial cell response in pleurodesis induced by talc still poses a challenge. The current results indicate that mesothelial cells may account for the inflammation seen in vivo.

The dose of talc used in this study was comparable to that used in human pleurodesis. If the surface of both pleural membranes in the rabbit $\left(200 \mathrm{~cm}^{2}\right)$ and in humans $\left(2,000 \mathrm{~cm}^{2}\right)$ is considered, the amount of talc used in vivo is approximately the same: in rabbits, $200 \mathrm{mg} \times 2.5 \mathrm{~kg} \cdot 200 \mathrm{~cm}^{-2}=2,500 \mu \mathrm{g} \cdot \mathrm{cm}^{-2}$ and in humans $5 \mathrm{~g} \cdot 2,000 \mathrm{~cm}^{-2}=2,500 \mu \mathrm{g} \cdot \mathrm{cm}^{-2}$.

The experimental finding that mesothelial cells may play a major role in the mechanism of pleural inflammation and contribute to an effective sclerosis in talc-induced pleurodesis may help explain why malignant pleural effusions with a high tumour burden and a low pleural fluid $\mathrm{pH}$ and glucose concentration may be less responsive to talc-pleurodesis than malignant effusions with less malignant involvement of the pleural space [18-22]. However, this is not absolute because effective pleurodesis can be achieved using talc by thoracoscopy despite the findings of low pleural fluid $\mathrm{pH}$ [23]. In conclusion, the present findings indicate that the acute inflammatory process in talc pleurodesis may have the active contribution of the mesothelial cells.

\section{ACKNOWLEDGEMENTS}

The authors would like to thank K.S. Sayuri, L.P. Almeida, and C.S.R. Silva for their valuable collaboration.

\section{REFERENCES}

1 Light RW. Pleural diseases. 4th Edn. Philadelphia, Lippincot Williams \& Wilkins, 2001.

2 Waker-Renard PB, Vaughan LM, Sahn SA. Chemical pleurodesis for malignant pleural effusions. Ann Intern Med 1994; 120: 56-64.

3 Marchi E, Teixeira LR, Vargas FS. Management of malignancy-associated pleural effusion. Current and future treatment strategies. Am J Respir Med 2003; 2: 261-273.

4 Dikensoy O, Light RW. Alternative widely available, inexpensive agents for pleurodesis. Curr Opin Pulm Med 2005; 11: 340-344.

5 Webb WR, Ozmen V, Moulder PV, Shabahang B, Breaux J. Iodized talc pleurodesis for the treatment of pleural effusions. J Thorac Cardiovasc Surg 1992; 103: 881-886.

6 Yim APC, Chan ATC, Lee TW, Wan IYP, Ho JKS. Thoracoscopic talc insufflation versus talc slurry for symptomatic malignant pleural effusion. Ann Thorac Surg 1996; 62: 1655-1658.

7 de Campos JR, Vargas FS, Werebe E, et al. Thoracoscopy talc poudrage: a 15-year experience. Chest 2001; 119: 801-806.

8 Paschoalini MS, Vargas FS, Marchi E, et al. Prospective randomized trial of silver nitrate versus talc slurry in pleurodesis for symptomatic malignant pleural effusions. Chest 2005; 128: 684-689.

9 Kennedy L, Sahn SA. Talc pleurodesis for the treatment of pneumothorax and pleural effusion. Chest 1994; 106: 1215-1222.

10 Van Den Heuvel MM, Smith HJM, Barbierato SB, Havenith CEG, Beelan RHJ, Postmus PE. Talc-induced 
inflammation in the pleural cavity. Eur Respir J 1998; 12: 1419-1423.

11 Nasreen N, Hartman DL, Mohammed KA, Antony VB. Talc-induced expression of C-C and C-X-C chemokines and intercellular adhesion molecule-1 in mesothelial cells. Am J Respir Crit Care Med 1998; 158: 971-978.

12 Lee YC. Cytokines in pleural diseases. In: Light RW, Lee YC. Textbook of Pleural Diseases. Arnold Publishers, London, 2003; pp. 63-89.

13 Marchi E, Vargas FS, Acencio MMP, et al. Talc and silver nitrate induce systemic inflammatory effects during the acute phase of experimental pleurodesis in rabbits. Chest 2004; 125: 2268-2277.

14 Light RW, Cheng DS, Lee YC, et al. A single intrapleural injection of transforming growth factor-beta (2) produces an excellent pleurodesis in rabbits. Am J Respir Crit Care Med 2000; 162: 98-104.

15 Gary Lee YC, Melkerneker D, Thompson PJ, et al. Transforming growth factor beta induces vascular endothelial growth factor elaboration from pleural mesothelial cells in vivo and in vitro. Am J Respir Crit Care Med 2002; 165: 88-94.

16 Anthony VB, Nasreen N, Mohammed KA, et al. Talc pleurodesis: basic fibroblast growth factor mediates pleural fibrosis. Chest 2004; 126: 1522-1528.
17 Vargas FS, Teixeira LR, Vaz MAC, et al. Silver nitrate is superior to talc slurry in producing pleurodesis in rabbits. Chest 2000; 118: 808-813.

18 Teixeira LR, Vargas FS, Antonangelo L, et al. Low concentration silver nitrate pleurodesis in rabbits: optimal concentration for rapid and complete sclerosing effect. Lung 2003; 181: 353-359.

19 Genofre EH, Vargas FS, Antonangelo L, et al. Ultrastructural acute features of active remodeling after chemical pleurodesis induced by silver nitrate or talc. Lung 2005; 183: 197-207.

20 Good JT, Taryle DA, Sahn SA. The pathogenesis of low glucose, low pH malignant effusions. Am Rev Respir Dis 1985; 131: 737-741.

21 Sahn SA, Good JT Jr. Pleural fluid $\mathrm{pH}$ in malignant effusions: diagnostic, prognostic and therapeutic implications. Ann Intern Med 1988; 108: 345-349.

22 Rodríguez-Panadero F, López Mejías J. Low glucose and $\mathrm{pH}$ levels in malignant pleural effusions. Diagnostic significance and prognostic value in respect to pleurodesis. Am Rev Respir Dis 1989; 139: 663-667.

23 Aelony Y, King RR, Boutin C. Thoracoscopic talc poudrage in malignant pleural effusions: effective pleurodesis despite low pleural pH. Chest 1998; 113: 1007-1012. 